\title{
TINJAUAN PRINSIP - PRINSIP DESAIN PERTAMANAN PADA MASJID TAMAN WISATA IMAN SITINJO KABUPATEN DAIRI
}

\author{
Darmanto Silalahi $^{1^{*}}$, Daulat Saragi ${ }^{2 *}$, Adek Cerah Kurnia Azis ${ }^{3 *}$, Sugito $^{4 *}$ \\ Program Studi Pendidikan Seni Rupa Jurusan Seni Rupa Fakultas Bahasa dan Seni \\ Universitas Negeri Medan \\ Jl. Willem Iskandar Pasar V Medan Estate, Kec, Percut Sei Tuan, Kab. Deli Serdang, Kode Pos 20371 \\ Sumatera Utara. Indonesia \\ Email: silalahidarmanto190895@gmail.com
}

\begin{abstract}
Abstrak
Penelitian ini bertujuan untuk mengetahuiprinsip-prinsip desain pada masjid Taman Wisata Iman yang terdapat di daerah Sitinjo Kabupaten Dairi. Penelitian ini dilaksanakan di Daerah Taman Wisata Iman Sitinjo Kabupaten Dairi khususnya pada Taman Masjid. Dipilihnya daerah ini menjadi objek penelitian karena daerah wisata ini tidak terlepas dari keberadaan tamannya karena taman sangat berfungsi untuk memperindah dan menambah daya tarik suatu daerah wisata. Pada penelitian ini taman yang akan diteliti hanya berfokus pada taman masjid saja, namun peneliti taman ini menjadi3 (tiga) bagian taman yaitu Taman Depan, Taman Samping, dan Taman Inti.Metode yang digunakan dalam mengumpulkan data yaitu: Metode Observasi, Wawancara, dan Dokumentasi.Dari hasil penelitian ini berdasarkan penerapan prinsip-prinsip desain pertamanan pada Masjid Taman Wisata Iman Sitinjo Kabupaten Dairi yang telah di presentasekan maka dapat disimpulkan bahwa Taman Depan dinilai cukup $(3,8)$, Taman Samping dinilai sangat kurang $(1,8)$, dan Taman Inti dinilai cukup $(3,5)$. Dari presentase ketiga taman maka dirata-ratakan dinilai cukup $(3,0)$ dalam menerapkan prinsipprinsip desain pertamanan. Untuk itu maka dibutuhkan suatu pemikiran untuk memberikan suatu perhatian khusus terhadap pembuatan taman yang baik yaitu dengan suatu perencanaan yang matang dengan menerapkan prinsip-prinsip desain pertamanan sehingga setiap penempatan unsur-unsur taman tertata dengan baik dan hasilnya menjadikan taman yang indah dan menarik perhatian para pengunjung.
\end{abstract}

Kata Kunci: prinsip desain taman, masjid, RWI

\begin{abstract}
This study aims to determine the design principles of the Taman wisataImanmosque in the Sitinjo area of Dairi Regency. This research was carried out in the Area of Taman Wisata Iman Sitinjo, Dairi Regency, especially in the Mosque Park.This area was chosen as the object of research because this tourist area is inseparable from the existence of the park because the park is very functioning to beautify and add to the attractiveness of a tourist area.In this study the park that will be studied only focuses on the mosque park, but the researchers of this park become 3 (three) parts of the park, namely the Front Garden, the Side Garden, and the Core Park. The method used in collecting data is: Observation, Interview, and Documentation Methods. From the results of this study based on the application of the principles of gardening design at the Taman Wisata Iman Sitinjo Mosque in Dairi District which has been presented, it can be concluded that the Front Garden is considered sufficient (3.8), the Side Park is considered very lacking (1.8), and the Park The core is considered sufficient (3.5). From the third percentage of the park, it is averaged enough (3.0) to apply the principles of landscape design. For that reason, a thought is needed to give a special attention to the making of a good garden, namely with a careful planning by applying the principles of landscape design so that each placement of the elements of the garden is well organized and the results make the garden beautiful and attract the attention of visitors.
\end{abstract}

Keywords: design principles, mosque, RWI

\section{PENDAHULUAN}

Setiap daerah wisata yang terdapat di Indonesia memiliki keunikan dan ciri khas tersendiri baik dari keindahan alam, sejarah, maupun budaya masyarakat yang sifatnya alamiah dan menjadi sesuatu yang dapat dipahami keberadaannya. Demikian halnya dengan daerah taman wisata iman Kecamatan Sitinjo 


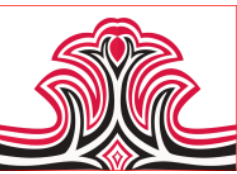

Kabupaten Dairi merupakan daerah wisata yang memiliki keunikan tersendiri.

Daerah wisata ini dibangun oleh pemerintah Kabupaten Dairi pada tahun 2001 tepatnya di daerah perbukitan Sitinjo yang terletak di kecamatan Sitinjo. Adapun pertimbangan sehingga taman wisata iman di tempatkan di lokasi tersebut dipenuhi oleh pohon Pinus dan dinilai sangat bagus dan cocok menambah kesejukan alam wisata rohani.

Taman Wisata Iman bukan hanya mewakili salah satu agama saja yang di akui di Indonesia melainkan semua agama dihadirkan dalam berbagai bangunan arsitektur rumah ibadah serta taman yang mendukung untuk keindahan taman wisata. Mewakili yang dimaksud adalah bahwa dalam Taman Wisata Iman terdapat berbagai bangunan-bangunan rumah ibadah dengan ciri khas yang di anggap bersejarah bagi pemeluk agama masing-masing.

Dengan kehadiran arsitektur bangunan peribadatan ini dan sejuknya alam serta adanya nuansa rohani yang kuat dalam taman ini dapat menumbuhkan rasa para pengunjung ingin menikmati keindahan daerah wisata ini baik dari dalam maupun dari luar semakin meningkat. Namun melihat kondisi taman wisata Iman khususnya di masjid banyak dijumpai tanamantanaman yang kurang mendukung untuk suatu taman wisata karena kurangnya perhatian atau kurangnya penataan terhadap suatu taman sehingga mengurangi fungsi dari taman tersebut. Tata atur merupakan gambaran merancang yang cukup jelas dan taat asas sehingga mudah dinyatakan dengan kata dan gambar. Jadi, dengan adanya tata atur dalam suatu taman dapat menambah keindahan dan kenyamanan sehingga terpenuhinya fungsi dari taman tersebut. Sedangkan kita ketahui bahwa fungsi suatu taman adalah lebih mengutamakan fungsi keindahan, kenyamanan, dan kesenangan. Dengan demikian hal ini menjadi pendorong bagi pemerintah Kabupaten Dairi untuk membangun daerah tersebut menjadi objek wisata rohani dengan menempatkan sektor parawisata ini menjadi salah satu prioritas pada pembangunan daerah.

Dalam pembangunan daerah wisata tidak terlepas dari berbagai faktor yang dapat mempengaruhi cepat atau lambatnya untuk mencapai apa yang diharapkan dan di antara faktor-faktor yang mempengaruhi perkembangan daerah wisata adalah keberadaan pertamanan. Keberadaan pertamanan berperan penting dalam suatu wisata karena taman berfungsi untuk menambah keindahan, kenyamanan dan rasa senang
Gorga Jurnal Seni Rupa

Volume 08 Nomor 01 Januari-Juni 2019

p-ISSN: 2301-5942 | e-ISSN: 2580-2380

bagi para pengunjung dengan menempatkan unsur dan jenis taman yang tertata dengan baik.

Disamping sebagai penambah keindahan, kenyamanan dan rasa senang, keberadaan taman masjid pada keseluruhannya merupakan pencerminan makna daerah wisata tersebut. Yang mencerminkan adanya suatu hubungan yang erat antara taman dengan daerah tersebut, sehingga perlu sekali adanya suatu pertimbangan dan perencanaan yang matang terutama dalam menerapkan prinsip-prinsip desain pertamanan karena perencanaan dan pembuatan taman tidak akan terlepas dari hal tersebut.

Disamping itu dalam perencanaan dan pembuatan taman masjid perlu sekali adanya suatu proses pemilihan terhadap jenis-jenis taman yang akan di buat serta mengetahui unsur apa yang akan dimasukkan ke dalamnya. Karena ini merupakan langkah dasar untuk pembuatan taman yang baik dan dapat dinilai sebagai suatu karya seni yang tentunya bermanfaat dan dapat dinikmati oleh para pengunjung.

Jadi tidak tercapainya tujuan ataupun fungsi taman masjid yang sesungguhnya, ini di sebabkan oleh kurangnya suatu perencanaan yang matang dimana belum adanya suatu penerapan prinsip-prinsip desain pertamanan sehingga taman belum dapat digolongkan sebagai karya seni yang menunjukkan keindahan, kenyamanan dan memiliki fungsi bagi para pengunjung.

Hal ini yang sangat menarik untuk diteliti karena melihat kurangnya prinsip-prinsip dan unsur-unsur perancangan taman ataupun tata atur dalam taman wisata Iman khususnya di masjid sehingga penulis mencoba menganalisis Tinjauan Prinsip-Prinsip Desain Pertamanan Pada Masjid Taman Wisata Iman Sitinjo Kabupaten Dairi.

\section{KAJIAN TEORI}

\section{Kreativitas}

Desain adalah dorongan keindahan yang mewujudkan dalam suatu bentuk komposisi; rencana komposisi; suatu yang memiliki kekhasan; atau garis besar suatu komposisi, misalnya bentuk yang berirama, desain motif, komposisi nada, dan lain-lain(Sachari,2005).

\section{Taman}

Taman merupakan elemen pelengkap yang dapat memperindah lingkungan sekitarnya terutama untuk objek mati seperti bangunan(Hart2iningsih, 2017:11). 


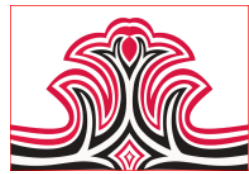

3.Jenis-Jenis Taman

1. Taman makro atau Macro garden

2. Taman mini atau Miniature garden

3. Taman mikro atau Micro garden

\section{Penggolongan Atas Faktor Kelembaban Taman}

1. Material lunak atau (Soft materials)

2. Material keras atau (Hard materials)

\section{Fungsi Taman}

Fungsi pertama yang mudah dikenali adalah fungsi estetika, fungsi ini berkaitan dengan suatu kondisi yang berkaitan dengan sensasi keindahan yang dirasakan seseorang, tetapi rasa keindahan tersebut baru akan dirasakan apabila terjadi perpaduan yang harmonis dari elemen-elemen keindahan yang terkandung pada suatu objek (Artini, 2004:5).

Fungsi taman ini tergolong menjadi beberapa bagian, yaitu : fungsi secara arsitektural, fungsi estetika, fungsi secara teknik, fungsi sebagai pengendali iklim, dan fungsi rekreasi.

\section{Prinsip-Prinsip Perencanaan Taman}

Sebuah desain yang baik akan tercipta dari kesesuaian komposisi dan penyusunan berbagai elemen (Sintia,2004:21). Maka perencanaan dan pembuatan taman harus berdasar pada prinsip-prinsip desain pertamanan: Susunan (order), kesatuan (unity), dominasi (dominance), kontras utama (major contrast), pengulangan (repetition), irama dan ritme (rhythm), penghubung (interconnection), dan keseimbangan (balance).

\section{Susunan}

Susunan merupakan dasar penting untuk bentuk yang baik. Tanpa susunan, sesuatu tidak akan berbentuk. Manusia, sebagai makhluk yang berpikiran teratur, menginginkan suatu susunan yang membuat sesuatu yang tak menentu menjadi sesuatu yang jelas. salah satu dasar prinsip desain pertamanan adalah susunan.

\section{Kesatuan}

Kesatuan (Unity) diartikan sebagai sebuah hubungan yang harmonis antara berbagai elemen yang digunakan dan karakteristiknya. Kesatuan dapat dilihat dari bentuk, material yang digunakan, warna, tekstur dan karakternya (Sintia, 2004:21).

\section{Dominasi}

Dominasi adalah kesatuan pengaruh satu elemen taman yang menonjol terhadap elemen lainnya, bentuk dominan tersebut bisa berupa ukuran, bentuk, tekstur,
Gorga Jurnal Seni Rupa

Volume 08 Nomor 01 Januari-Juni 2019

p-ISSN: 2301-5942 | e-ISSN: 2580-2380

warna atau lokasi elemen dalam kesatuan elemenelemen taman lainnya.

\section{Kontras Utama}

Kontras utama adalah sesuatu yang dimunculkan dari keseluruhan unsur sehingga lebih menonjol dibandingkan dengan unsur lainnya (Artini, 2004:137).

\section{Pengulangan}

Prinsip pengulangan adalah suatu teknik yang menggunakan pengulangan satu elemen taman di beberapa lokasi yang berbeda tetapi mempunyai kesan bersambung antar lokasi.

\section{Irama atau Ritme}

Prinsip ini sangat berhubungan dengan prinsip pengulangan sebelumnya sehingga tercipta keharmonisan kesatuan antar elemen taman lainnya. Pengulangan tersebut akan menciptakan irama dalam sebuah desain pertamanan. Keunikan prinsip ini adalah cara menarik minat dan perhatian pengguna taman serta mengarahkannya dari suatu ruang ke ruang berikutnya.

\section{Penghubung}

Penghubung adalah cara sebuah elemen taman menjadi penghubungan dari sebuah susunan yang terdiri dari berbagai elemen yang digunakan dalam suatu desain taman.

\section{Keseimbangan}

Prinsip terakhir yang perlu diperhatikan adalah keseimbangan dari susunan elemen taman secara keseluruhan. Ada dua tipe keseimbangan, yaitu keseimbangan simetris dan asimetris (tidak simetris). Keseimbangan simetris terlihat dari kesamaan susunan di dua sisi ruang sisi sebelah kanan sama dengan sisi sebelah kiri, jika tidak sama akan tercipta keseimbangan asimetris dengan cara membedakan ukuran, tekstur, atau bentuk dari satu elemen yang lebih dominan.

\section{Unsur-Unsur Pertamanan}

Unsur-unsur pertamanan adalah materi-materi yang digunakan sebagai bahan yang merupakan komponen pertamanan itu sendiri.Materi-materi alam itu antara lain: unsur geologi, unsur-unsur hortikultura, unsur zoology, dan unsur kreasi manusia.

\section{METODE PENELITIAN}

Analisis data adalah proses mencari dan menyusun secara sistematis data yang diperoleh dari hasil 


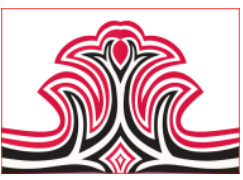

wawancara, catatan lapangan, dan bahan- bahan lain, sehingga dapat mudah dipahami, dan temuannya dapat diinformasikan kepada orang lain. Analisis data dilakukan dengan mengorganisasikan data, menjabarkan ke dalam unit-unit, melakukan sintesa, menyusun ke dalam pola, memilih mana yang penting dan yang akan dipelajari, dan membuat kesimpulan yang dapat diceritakan kepada orang lain(Sugiyono, 2016:334)

Lokasi penelitian ini dilaksanakan di daerah Taman Wisata Iman Sitinjo Kabupaten Dairi.Penelitian ini dilaksanakan bulan Juli 2018 sampai dengan bulan Agustus 2018 sekaligus dengan penyusunan laporan penelitian, yang kemudian dilanjutkan dengan ujian Skripsi.

Dari hasil dokumentasi dan hasil rekaman gambar serta wawancara, sekaligus menganalisis lembar pengamatan yang telah dibuat sebelumnya. Teknik pengumpulan tersebut antara lain: metode observasi merupakan langkah pertama untuk mengamati secara langsung objek penelitian untuk memperoleh data dimana data yang didapatkan adalah sebagai dasar untuk penilaian ataupun untuk proses menganalisis objek yang diteliti, wawancara digunakan sebagai teknik pengumpulan data apabila peneliti ingin melakukan studi pendahuluan untuk menemukan permasalahan yang harus diteliti, dan juga apabila peneliti ingin mengetahui ha-hal dari responden yang lebih mendalam dan jumlah respondennya sedikit/kecil, Di dalam melaksanakan metode dokumentasi, peneliti menyelidiki benda-benda tertulis seperti buku-buku, majalah, dokumen, peraturan-peraturan, notulen rapat, catatan harian, dan sebagainya (Arikunto, 2010:201) .

\section{Instrumen dan Alat Penelitian}

Instrumen yaitu alat atau fasilitas yang digunakan oleh peneliti dalam mengumpulkan data agar pekerjannya lebih mudah dan hasilnya lebih baik dalam arti lebih cermat, lengkap dan sistematis sehingga lebih mudah diolah (Arikunto, 2010:203).

\section{Teknik Analisis Data}

Adapun teknik analisis data yang digunakan adalah analisis deskriptif kualitatif, yaitu mengadakan penelitian terhadap data yang diperoleh dan akan dibandingkan dengan teori pertamanan khususnya dalam penerapan prinsip-prinsip desain. Data yang diperoleh akan dinilai menggunakan instrumen tiga orang pengamat atau disebut responden.
Gorga Jurnal Seni Rupa

Volume 08 Nomor 01 Januari-Juni 2019

p-ISSN: 2301-5942 | e-ISSN: 2580-2380

maka peneliti akan menggunakan perhitungan untuk mencari niai rata-rata :

$$
: \mathrm{M}(\mathrm{R})=\frac{\sum x}{N} \times 100 \%
$$

\section{Keterangan: \\ $\mathrm{M}:$ Mean \\ $\sum \mathrm{x}$ : Nilai Semua Skor}

$\mathrm{N}$ : Jumlah Responden

Frekuensi jawaban responden $\left(\sum \mathrm{x}\right)$ dan jumlah responden $(\mathrm{N})$ diperoleh dari penilaian dengan menggunakan tabel penilaian oleh tiga orang responden sesuai dengan kriteria penilaian yang sudah ditentukan.

\section{HASIL DAN PEMBAHASAN \\ 1.Hasil}

Berdasarkan hasil penelitian penulis dilapangan yang meneliti tinjauan prinsip-prinsip desain pertamanan pada Taman Wisata Iman Sitinjo Kabupaten Dairi.

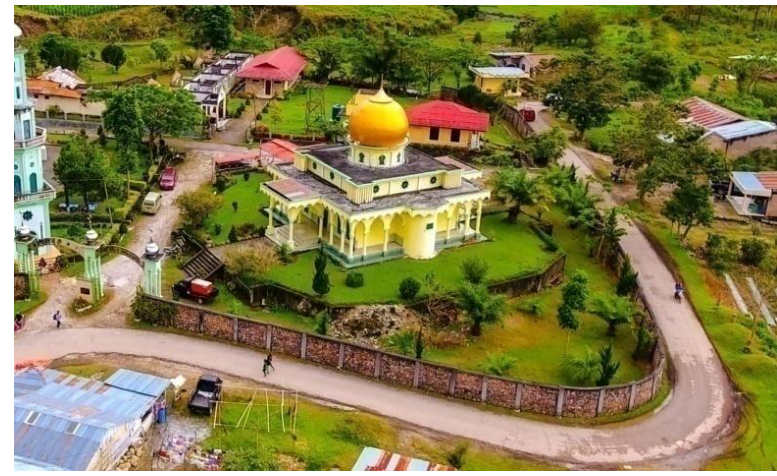

Gambar 1. Lokasi Taman Keseluruhan Yang Dibatasi Pagar Tembok dan Jalan (Sumber: Darmanto Silalahi, 2018)

\section{Pembahasan \\ 1).Taman Depan}

Analisis data keseluruhan dari tiga responden adalah responden $1=3,6$ responden $2=3,75$ dan responden 3 $=4,25$ dan total rata-rata adalah 3,8 dengn nilai cukup dalam penerapan prinsip-prinsip desain pertamanan. Pada taman ini masih kita jumpai kekurangan unsurunsur tamanbaik alami maupun buatan manusia dan belum menunjukkan karakter yang jelas. 


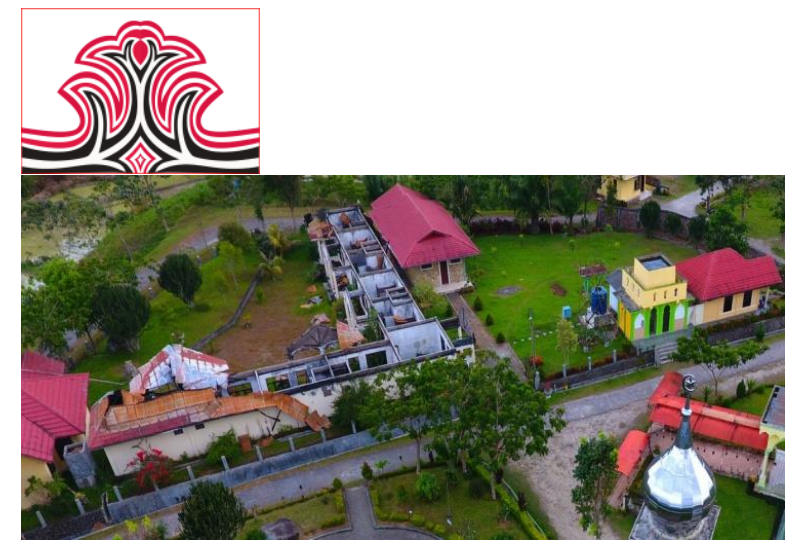

Gambar 2. Lokasi Keseluruhan Taman Samping (Sumber: Darmanto Silalahi, 2018)

\section{2).Taman Samping}

Dari nilai keseluruhan tamaan samping dinilai dari ketiga responden adalah responden $1=2,3$ responden 2 $=1,6$ dan responden $3=1,6$ dan total rata-rata adalah 1,8 dengan nilai sangat kurang dalam penerapan prinsip-prinsip desain pertamanan. Pada taman ini belum dijumpai karakter yang jelas karena taman yang dibuat hanya sekedar menutupi pinggiran jalan dan tanah kosong, sehingga unsur tanaman cenderung kita jumpai tidak teratur.

\section{3).Taman Inti}

Dari hasil keseluruhan taman inti dinilai cukup $(3,5)$. Dalam penerapan prinsip-prinsip desain pertamanan, pada taman ini unsur tanaman letaknya masih kurang teratur dan jenis tanaman perlu adanya penambahan sehingga sesuai dengan lahan yang cukup luas.

\section{KESIMPULAN DAN SARAN}

\section{Kesimpulan}

Hasil penelitian yang dilakukan di Taman Masjid Wisata Iman Sitinjo Kabupaten Dairi berdasarkan penerapan prinsip-prinsip desain pertamanan dapat disimpulkan sebagai berikut: Dari semua penelitian terhadap Taman Wisata Iman khususnya pada taman masjid dalam penerapan prinsip-prinsip desain pertamanan disimpulkan bahwa Taman Depan dinilai cukup (3,8), Taman Samping dinilai sangat kurang $(1,8)$, dan Taman Inti dinilai cukup $(3,5)$. Dari presentase ketiga taman maka dapat dirata-ratakan dengan dinilai cukup $(3,0)$.

\section{Saran}

Berdasarkan hasil analisis yang perlu diperhatikan oleh pemerintah daerah kabupaten dairi adalah: Dalam merencanakan dan membuat taman selalu berpedoman pada prinsip-prinsip desain pertamanan, menempatkan unsur-unsur taman secara tepat sehingga tidak mengganggu dan mengurangi daya tarik daerah wisata tersebut, dan untuk lebih memprioritaskan taman sebagai salah satu hal yang dapat menarik perhatian bagi para pengunjung.
Gorga Jurnal Seni Rupa

Volume 08 Nomor 01 Januari-Juni 2019

p-ISSN: 2301-5942 | e-ISSN: 2580-2380

\section{DAFTAR RUJUKAN}

Arikunto, Suharsimi. (2010). Prosedur Penilitian (Suatu Pendekatan Praktek). Jakarta: Rineka Cipta.

Fireza, Doni. (2007). Desain Taman Islami (Ramah, Indah, Dan Penuh Berkah). Jakarta: Hikmah. 